\title{
Religious Practice and/as Future Making in Africa: Some Cautionary Remarks
}

\author{
Dorothea Schulz
}

1

Introduction

Are the notions of 'futurity' and 'future making' productive heuristic devices with which to study religion in Africa? More specifically, are they good thinking tools for examining the nature of religious engagement and aspirations in sub-Saharan Africa? If so, what new insights does a focus on futurity and future making yield?

In response to these questions, I propose three points for further debate. First, much anthropological scholarship on religion in Africa, and on Christianity in particular, has not explicitly addressed the future as an object of reflection and investigation. Still, and this is my second point, a number of anthropological investigations into close thematic affiliates to the future, such as 'time', 'temporality', and 'memory', have generated important insights into diverse, sometimes overlapping, and historically determinate conceptions of temporality and historicity in African societies. Third, the contrast between studies that touch on questions of futural orientations (Bryant and Knight 2019) and those that directly address religious practice as future making raises the question of how an explicit focus on the future might enrich scholarly understandings of religious aspirations and controversies in sub-Saharan Africa, past and present.

As an entry point into the discussion, I shall sketch out dominant trends in contemporary anthropological scholarship of the future, and then ask how this scholarship has thought about the relationship between religion and the future.

Anthropological Perspectives on Future Making: A Sketchy Literature Review

Several authors claim that the mushrooming of anthropological investigations of futurity and future making since, roughly, the turn of the century, marks a significant departure from anthropologists' long-time neglect of the topic. Drawing on Nancy Munn, the authors argue that this neglect reflects foundational assumptions of the discipline (Munn 1992; cf. Gell 1992), in particular a

(C) DOROTHEA SCHULZ, 2022 | DOI:10.1163/9789004471641_006 
conceptual contrast between 'modernity' and 'tradition' that locked the subjects of enquiry as 'others' in an alleged orientation towards the past, denied them 'coevalness' (Fabian 1983) and future-oriented agency (Bryant and Knight 2019; Robbins 2001; Salazar et al. 2017; Strzelecka 2013). In contrast, Valentine and Hassoun (2019: 244), harking back to an older debate on the discipline's theoretical and methodological foundations and to a social science futurology of the 196os that addressed the future as something to be studied through actors' present actions, maintain that anthropology's interest in the future is far from novel. In so doing, the scholars recognize that human actors situate their actions within ordering schemes comprising visions of the past and of the future (see also Adam 2004).

Regardless of whether we frame these antecedents of present anthropological scholarship through the temporalities of continuity or rupture, an evident departure from these predecessors consists in a firm (though not always successful) disengagement from the normative assumptions and modernization agenda that informed the earlier social science futurology and its concern with 'development planning' and promoting social change towards a future aligned with a Western-style modernization paradigm. Sociological reflection on future making posited a dichotomy between a 'modern', future-oriented (industrialized) West and a tradition-bound 'rest of the world' for which a promising future needed to be orchestrated and facilitated.

Anthropological work on the future since the 2000 s also differs from the earlier futurology in its varied conceptual approaches to and analytical perspectives on culturally specific and changing conceptions of futurity and of orientations towards the future. Various authors draw on existing work on temporalities, historicities and memory politics, to study how people's conceptualizations of the future orient and shape their daily lives and struggles (for example Cooper and Pratten 2014; Pandian 2012). This in turn has refuelled debate on how investigations into the future could redefine the future of the anthropological discipline (for example Pandian 2019; Strzelecka 2013). In making people's orientations towards the future a guiding empirical concern, anthropologists propose complementary analytical lenses (Appadurai 2013; Bryant and Knight 2019; Salazar et al. 2017). Appadurai conceives of the future as a cultural horizon, which is moulded by cultural values and thus never a neutral space. Values and perceptions, formulated at the individual level, mirror collective perceptions, choices, and preferences. This imaginary framework, Appadurai argues, is "shot through with affect and with sensations" that generate "various configurations of aspiration, anticipation, and imagination", configurations that jointly produce "the future as a specific cultural form or horizon" (Appadurai 2013: 286f). By highlighting aspiration and anticipation as modalities of future orientation, Appadurai prioritizes an empirical focus 
on culturally variable value repertoires that inform and delimit social actors' aspirations and projections of a desirable future. Yet, according to Bryant and Knight (2019), for scholars to reclaim "the future as a central dimension of our temporality", they also need to consider the diverse modalities, directionalities, and temporalities inherent in future making. Bryant and Knight single out expectation, speculation, potentiality, hope, and destiny as modalities that, while not always clearly distinguishable from each other, need to be understood as different 'futural orientations'. Drawing on Theodore Schatzki's (2010) notion of 'vernacular timespaces', they stress historical variation and specificity of these futural orientations and their inherent affective qualities and teleologies (Bryant and Knight 2019: 12-19).

Authors also ask what historical dynamics fuel the renewed social science interest in the future (for example Appadurai 2016; Kleist and Jansen 2016; Ortner 2016; Valentine and Hassoun 2019). They disagree on whether or not the new preoccupation with the future should be read as mirroring the zeitgeist of the neoliberal world order, a zeitgeist characterized by a one-sided insistence on 'open ended' futures that are replete with possibilities of individual choice, responsibility, entrepreneurial undertaking and success.

As much as these different strands of scholarly debate have expanded our analytical perspectives on the future, they have, with few exceptions (such as Roman 2019) made little effort to discuss religious practice as future making. That is, rather than recognize the existence of an interstitial domain coconstituted by people's futural orientations and religious engagements, little room has been given to how the individuals or collectivities highlighting religious concerns integrate their visions of futurity into their daily mundane and eschatological aspirations and considerations. The blind spot is striking in that, for obvious reasons, practitioners of religious traditions, in Africa and elsewhere, view a connection between these two dimensions of their everyday struggles, and tie their expectations and projects of future making to religious aspirations.

How, then, have anthropological studies addressed actors' futural orientations in connection with their religious practices? My response to this question centres on a particular field of anthropological scholarship, namely investigations of Christianity in Africa.

\section{Africanist Scholarship on Christianity: Religious Practice as Future Making?}

In discussing how the future has figured in scholarship on Christianity in Africa, for the purpose of clarity, I propose to distinguish conceptually between 
two understandings of futurity and the distinct temporalities of the future they imply. The conceptual distinction is relevant for discussions on religion and future making in Africa, for appreciating how scholars of Christianity address the future in their studies and how a disregard of the conceptual distinction might limit some of their insights.

The first understanding of futurity, which I call 'life-trajectory future', refers to what actors envision as a (desirable or potential) future in the here and now, and to related aspirations, such as achieving prosperity, well-being and a good reputation.

The second ('eschatological') future designates what religious actors consider the ultimate reference point of their aspirations, actions, and struggles to conform to religious prescripts, a reference point that in the Christian, Islamic and Jewish traditions is located in the afterlife. Drawing a distinction between the two notions of futurity affords a nuanced understanding of the aspirations of actors who highlight the importance of religious and ethical ideals to their everyday life (see Schulz 2012, 2020).

If at all, it is studies on millennial Christian movements in Africa that have explicitly engaged questions of futurity and temporality. The studies demonstrate that people's expectations of an eschatological future shape their efforts, individual and collective, to align their lives with religious prescripts and to follow a particular leader (Dekmejan and Wyszomirski 1972; Peires 1989; Vokes 2009). However, these relatively few case studies of millennial Christianity in colonial and postcolonial Africa do not systematically address interconnections between religion and future making, for instance by asking about actors' understandings of futurity, how they inform their religious engagements, or what tensions might emerge between immediate and eschatological concerns and aspirations.

Even if other work on Christianity in Africa rarely thematizes future making per se, there are authors who address questions of temporality and of believers' aspirations towards personal improvement and social progress. Particularly noteworthy are studies that, based on a historically contextualized account of plural African religious landscapes, address the 'why and how' (Robbins 2004: xxvii) of conversion to Christianity. Peel (1995), Jean and John Comaroff $(1991,1997)$, and Meyer (1999) have shown that missionary education and the acquisition of literacy offered converts important incentives for and trajectories of future making. Scholars also argued that Christian conversion entailed a 'conversion to modernity' (for example, van der Veer 1996), involving broader personal and social transformation tied to the prospect of becoming 'modern' Africans (for example, Engelke 2004; Luig 1997; Maxwell 2007; Maxwell and Lawrie 2013). Regardless of the variability of forms and degrees of 
conversion, Africans' decisions to adopt elements of Christian teachings and religious practices, past and present, were and are tied to visions of possible and desirable futures and to specific temporalities that inform these visions (for example Engelke 2014). Whereas Pentecostal conceptions of a future of redemption rest on a rhetoric of radical discontinuity with past practices and social obligations (van Dijk 20oo; Meyer 1999), mainline churches often envision Christian futures along a linear time line stretching seamlessly from the present to the future.

All these studies describe Christians' futural orientations as integral elements of their religious sensibilities without, however, asking how each of the two distinct understandings of futurity informs believers' daily mundane struggles, ethical and religious aspirations, and decisions to convert to Christianity. All authors implicitly give analytical priority to believers' immediate material and social concerns and hence to their aspirations to a 'here and now' future. Even scholars who mention that believers' secondary conversion to Pentecostal Christianity is prompted by their fear of damnation and related eschatological considerations, ultimately explain the attraction of Pentecostal churches in terms of the immediate economic advantages and prospects of upward social mobility offered by these churches (for example Marshall 2009; Ukah 2008). It is not always evident that the analytical prioritizing of the here and now future reflects actual preferences of those whose religious concerns are described. To ask anew which understanding of futurity fuels believers' actions, and to address their possibly conflicting aspirations as 'future making' could generate nuanced accounts of their self-understandings as religious subjects.

\section{$4 \quad$ Future Directions}

How might scholars of religion in sub-Saharan Africa draw on insights from recent scholarship on the future? And how might they, in turn, enrich this scholarship by exploring the intersections between religion and future making? Three lines of future investigation fall into place, each of which capitalizes on comparative work on the intersections between religious aspirations, temporalities and future making.

First, scholars should bring the perspectives developed for contemporary Pentecostal and Charismatic Christianity to bear on other forms of lived religion, regardless of whether they pertain to Christian, Muslim, Jewish or any other religious traditions. For instance, drawing a clear distinction between the immediate, current future and an eschatological future could enrich analysis of the - possibly generation-specific - ways in which Muslims narrate their 
religio-ethical aspirations and biographies. For scholars who focus on Islamic 'reform' or 'renewal' movements, considering the distinction between the two notions of futurity will elucidate how each of them informs Muslim decisions to break with established Muslim religious practices and return to allegedly more authentic interpretations. Given the religiously plural character of African settings, scholars should consider how protagonists of these different religious traditions formulate their visions of the future and ethico-religious aspirations in dialogue with and simultaneous contradistinction from each other, within and across boundaries of religious traditions.

Second, while the current anthropological 'moodswing' (Appadurai 2016; see Ortner 2016) towards the future has been productive and promising, one should not lose sight of the fact that future making involves specific constructions of the past, of continuities with or departures from the past and, in this sense, of 'historiopraxy' (Coleman 2011). Exploring religious actors' constructions of their relationship to the past should remain an overarching concern for scholarship on religion, in Africa and elsewhere. Understanding people's ethico-religious aspirations necessitates delving into their - often fraught orientations towards the past (for example, van Dijk 1997, 2000; Meyer 1999; Prince 2007; see Appadurai 1981) and the future. We need to explore how each of these temporal and spatial relocations serves as a framework within which to envision collective futures.

This brings me to a third line of investigation: scholars should explicitly address as a matter of future making the temporalities involved in actors' religious engagements; and probe which one of the understandings of futurity - a here and now as opposed to an eschatological future - inform these temporalities. This will enhance scholarly understanding of how each of the envisioned futurities inform, yet also limit, actors' struggles to build a future as well as their self-understandings as agentive subjects. This enquiry involves consideration, first, of the different constructions of temporality involved in people's religious engagements and aspirations; and second, of the possibility that notions of temporality inform actors' future aspirations in possibly paradoxical ways. Taking up Coleman's insights on 'historiopraxy', we can show that actors' orientations towards the future involve specific forms of history making (Coleman 2011) and evolve along the imaginary movement or 'emplacement' along social, spatial and temporal axes and 'timespaces' (see Schatzki 2010). Believers conjure up specific visions of individual relational and collective futures, in relation to broader constituencies of believers 'around the globe', and by locating their individual and collective efforts within specific constructions of the relationship between past, present and future. 


\section{References}

Adam, B. 2004. Towards a new sociology from the future. Paper NSoF Draft 3. http:// citeseerx.ist.psu.edu/viewdoc/download?doi=10.1.1.198.2175\&rep=rep1\&type=pdf [11 April 2019].

Appadurai, A. 1981. "The past as a scarce resource." Man (New Series), 16, 2: 201-219.

Appadurai, A. 2013. The future as cultural fact. Essays on the global condition. London: Verso.

Appadurai, A. 2016. "Moodswings in the anthropology of the emerging future." $H A U$ Journal of Ethnographic Theory, 6, 2: 1-4.

Bryant, R. and D. Knight. 2019. "Orientations to the future: An introduction." In Orientations to the future, edited by R. Bryant and D. Knight. http://americanethnologist. org/features/collections/orientations-to-the-future/orientations-to-the-future-anintroduction [11 April 2019].

Coleman, S. 2011. "'Right now': Historiopraxy and the embodiment of charismatic temporality." Ethnos, 76, 4: 426-447.

Comaroff, J. and J. L. Comaroff. 1991. Of revelation and revolution. Vol.1 (Christianity, colonization and consciousness). Chicago: The University of Chicago Press.

Comaroff, J. and J. L. Comaroff. 1997. Of revelation and revolution. Vol. 2 (The dialectics of modernity on a South African frontier). Chicago: The University of Chicago Press.

Cooper, E. and D. Pratten. 2014. "Ethnographies of uncertainty in Africa: An introduction." In Ethnographies of uncertainty in Africa, edited by E. Cooper and D. Pratten, 1-16. New York: Macmillan.

Dekmejian, R. and M. Wyszomirski. 1972. "Charismatic leadership in Islam: The Mahdi of Sudan." Comparative Studies in Society and History, 14, 2: 193-214.

Dijk, R. van. 1997. "From camp to encompassment. Discourses of transsubjectivity in the Ghanaian Pentecostal diaspora." Journal of Religion in Africa, 27, 2: 135-160.

Dijk, R. van. 20oo. "Christian fundamentalism in sub-Saharan Africa. The case of Pentecostalism." Occasional paper, Centre of African Studies, University of Copenhagen.

Engelke, M. 2004. "Discontinuity and the discourse of conversion." Journal of Religion in Africa, 34, 1/2: 82-109.

Engelke, M. 2014. "Christianity and the anthropology of secular humanism." Current Anthropology, 55, S10: S292-301.

Fabian, J. 1983. Time and the other: How anthropology makes its object. New York: Columbia University Press.

Gell, A. 1992. The anthropology of time: Cultural constructions of temporal maps and images. Oxford, Berg.

Kleist, N. and S. Jansen. 2016. "Introduction. Hope over time-crisis, immobility, and future-making." History and Anthropology, 27, 4: 373-392. 
Luig, U. 1997. Conversion as a social process. A history of missionary Christianity among the valley Tonga, Zambia. Hamburg: Lit.

Marshall, R. 2009. Political spiritualities. The Pentecostal revolution in Nigeria. Chicago: University of Chicago Press.

Maxwell, D. 2007. "Comment on Robbins." Current Anthropology, 48, 1: 25-26.

Maxwell, D. and I. Lawrie. 2013. Christianity and the African imagination. Essays in honour of Adrian Hastings. Leiden: Brill.

Meyer, B. 1999. Translating the devil. Religion and modernity among the Ewe in Ghana. Edinburgh: Edinburgh University Press for the International African Institute.

Munn, N. 1992. "The cultural anthropology of time. A critical essay." Annual Review of Anthropology, 21: 93-123.

Ortner, S. 2016. "Dark anthropology and its others: Theory since the eighties." $H A U$ Journal of Ethnographic Theory, 6, 1: 47-73.

Pandian, A. 2012. "The time of anthropology: Notes from a field of contemporary experience." Cultural Anthropology, 27, 4: 547-571.

Pandian, A. 2019. A possible anthropology. Methods for uneasy times. Durham: Duke University Press.

Peel, J. 1995. "For who hath despised the day of small things? Missionary narratives and historical anthropology." Comparative Studies in Society and History, 37, 3: 581-6o7.

Peires, J. 1989. The dead will arise: Nongqawuse and the great Xhosa cattle-killing movement of 1856-7. Bloomington: Indiana University Press.

Prince, R. 2007. "Salvation and tradition: Configurations of faith in a time of death." Journal of Religion in Africa, 37: 84-115.

Robbins, J. 2001. "Secrecy and the sense of an ending: Narrative, time, and everyday Millenarianism in Papua New Guinea and in Christian fundamentalism." Comparative Studies in Society and History, 43, 3: 525-551.

Robbins, J. 2004. Becoming sinners. Christianity and moral torment in a Papua New Guinea Society. Berkeley: University of California Press.

Roman, R. B. 2019. "Religious humanitarianism and fateful orientations among Pentecostal Kaale." In Orientations to the future, edited by R. Bryant and D. Knight. http://americanethnologist.org/features/collections/orientations-to-the-future/ religious-humanitarianism-and-fateful-orientations-among-pentecostal-kaale [11 April 2019].

Salazar, J. F., S. Pink, A. Irving and J. Sjöberg (Eds). 2017. Anthropologies and futures: Researching emerging and uncertain worlds. London: Bloomsbury.

Schatzki, T. 2010. The timespace of human activity: On performance, society, and history as indeterminate teleological events. New York: Lexington Books.

Schulz, D. E. 2012. Muslims and new media in West Africa. Pathways to god. Bloomington: Indiana University Press. 
Schulz, D. E. 2020. "'Trusting is a dicey affair': Muslim youth, gender relations, and future making in southwestern Uganda." In Waithood: Gender, education, and global delays in marriage, edited by M. C. Inhorn and N. J. Smith-Hefner, 6o-87. New York: Berghahn.

Strzelecka, C. 2013. "Anticipatory anthropology - anthropological future study." Prace Etnograficzne, 41, 4, 261-269. DOI: 10.4467/22999558.PE.13.023.1364.

Ukah, A. 2008. A new paradigm of Pentecostal power. A study of the Redeemed Christian Church of God in Nigeria. Lawrenceville, NJ: Africa World Press.

Valentine, D. and A. Hassoun. 2019. "Uncommon futures." Annual Review of Anthropology, 48: $243^{-26}$ o.

Veer P. van der. 1996. Conversion to modernities: The globalization of Christianity. New York: Routledge.

Vokes, R. 20og. Ghosts of Kanungu: Fertility, secrecy and exchange in the great lakes of East Africa. London: James Currey. 